\title{
Corrosion of Mechanically Alloyed Nanostructured FeAl Intermetallic Powders
}

\author{
A. Torres-Islas, ${ }^{1}$ C. Carachure, ${ }^{2}$ S. Serna, ${ }^{3}$ B. Campillo, ${ }^{4}$ and G. Rosas $^{2}$ \\ ${ }^{1}$ Facultad de Cencías Químicas e Ingeniería, P.E. I.M. Universidad Autónoma del Estado de Morelos, \\ Avenida Universidad 1001, Col. Chamilpa, 62210 Cuernavaca, MOR, Mexico \\ ${ }^{2}$ Instituto de Investigaciones Metalurgicas, UMSNH, Edificio U., Ciudad Universitaria, 58000 Morelia, MICH, Mexico \\ ${ }^{3}$ Centro de Investigacion en Ingeniería y Ciencias Aplicadas, UAEM, Avenida Universidad 1001, Col. Chamilpa, \\ 62210 Cuernavaca, MOR, Mexico \\ ${ }^{4}$ Facultad de Química, Instituto de Ingenieria, UNAM, Circuito Exterior S/N, Cd. Universitaria, 04510, Mexico
}

Correspondence should be addressed to A. Torres-Islas, atimarquis93@yahoo.com.mx

Received 13 September 2012; Accepted 29 November 2012

Academic Editor: Peter Majewski

Copyright (๑) 2012 A. Torres-Islas et al. This is an open access article distributed under the Creative Commons Attribution License, which permits unrestricted use, distribution, and reproduction in any medium, provided the original work is properly cited.

\begin{abstract}
The corrosion behavior of the $\mathrm{Fe}_{40} \mathrm{Al}_{60}$ nanostructured intermetallic composition was studied using electrochemical impedance spectroscopy (EIS) and linear polarization resistance (LPR) techniques with an innovative electrochemical cell arrangement. The $\mathrm{Fe}_{40} \mathrm{Al}_{60}$ (\% at) intermetallic composition was obtained by mechanical alloying using elemental powders of $\mathrm{Fe}(99.99 \%)$ and $\mathrm{Al}$ (99.99\%). All electrochemical testing was carried out in $\mathrm{Fe}_{40} \mathrm{Al}_{60}$ particles that were in water with different $\mathrm{pH}$ values. Temperature and test time were also varied. The experimental data was analyzed as an indicator of the monitoring of the particle corrosion current density $i_{\text {corr }}$. Different oxide types that were formed at surface particle were found. These oxides promote two types of surface corrosion mechanisms: (i) diffusion and (ii) charge transfer mechanisms, which are a function of $i_{\text {corr }}$ behavior of the solution, $\mathrm{pH}$, temperature, and test time. The intermetallic was characterized before and after each test by transmission electron microscopy. Furthermore, the results show that at the surface particles uniform corrosion takes place. These results confirm that it is possible to sense the nanoparticle corrosion behavior by EIS and LPR conventional electrochemical techniques.
\end{abstract}

\section{Introduction}

In the past, intermetallic materials based on aluminum with transition metals such as $\mathrm{Ni}, \mathrm{Ti}, \mathrm{Co}$, and $\mathrm{Fe}$ have been extensively investigated [1-9]. Particularly, the $\mathrm{Fe}_{40} \mathrm{Al}_{60}$ system has been very attractive due to several characteristics such as low cost, good mechanical performance at elevated temperatures, low density, and excellent oxidation-corrosion resistance. The $\mathrm{Fe}_{40} \mathrm{Al}_{60}$ develops an $\mathrm{Al}_{2} \mathrm{O}_{3}$ protective film, which provides good properties of corrosion resistance at high temperature $[10,11]$. It has also been reported that $\mathrm{Fe}_{40} \mathrm{Al}_{60}$ nanostructured material improves in general their physical properties [12]. In this sense, the mechanical alloying is an effective technique to achieve very fine crystal sizes (nanometer), thus getting better material properties [13]. Concerning $\mathrm{Fe}_{40} \mathrm{Al}_{60}$ intermetallic with nanosized particles $(100 \mathrm{~nm})$ obtained by mechanical alloying, there is no information related to their corrosion behavior in aqueous solution at long exposure times. This is due to the absence of a technique or equipment specifically designed for these purposes. However, in the present investigation an innovative electrochemical cell arrangement is employed to evaluate the $\mathrm{Fe}_{40} \mathrm{Al}_{60}$ (\% at) intermetallic corrosion behavior by means of EIS and LPR conventional electrochemical techniques. Furthermore, the aim of the present work is the application of such electrochemical techniques in $\mathrm{Fe}_{40} \mathrm{Al}_{60}$ intermetallic nanocrystals to monitor the aqueous corrosion performance for long periods of time.

\section{Experimental}

$\mathrm{Fe}_{40} \mathrm{Al}_{60}$ (\% at.) nanosized intermetallic powders were produced by mechanical alloying according to the procedure reported by Rosas et al. [14]. Figure 1 shows schematically the electrochemical cell experimental setup used for the EIS and LPR tests. The cell arrangement consists of a platinum 
wire as a working electrode with an exposed area of $0.2 \mathrm{~cm}^{2}$, a saturated calomel electrode (SCE) as reference electrode and a graphite auxiliary electrode. The electrodes were connected to a Gill AC (ACM instruments) potentiostat controlled by a personal desktop computer. Test solutions were prepared with sodium hydroxide and sulfuric acid analytical grade reagents and distilled water. The $\mathrm{pH}$ of the test solutions was adjusted prior to each test to $\mathrm{pH}$ values of 3,7 , and 11 . The $\mathrm{pH}$ measurements were made with an Oakton digital $\mathrm{pH}$ meter, previously calibrated. In all tests $0.125 \mathrm{~g}$ of $\mathrm{Fe}_{40} \mathrm{Al}_{60}$ intermetallic were used in $30 \mathrm{~mL}$ of aqueous test solutions. During every test the solution was agitated in turbulent regime. The electrochemical tests were carried out at $27^{\circ} \mathrm{C}$ and $70^{\circ} \mathrm{C}$ during 2 and 5 days, respectively. The $\mathrm{Fe}_{40} \mathrm{Al}_{60}$ powders were characterized by scanning electron microscopy (SEM) and transmission electron microscopy (TEM), before and after the electrochemical tests.

For the EIS tests the AC Gill potentiostat was calibrated according to the ASTM G106-89 Standard. The EIS test conditions were AC current signal with amplitude of $32 \mathrm{mV}$ at open circuit potential (OCP) in a frequency range of 30,000 to $0.01 \mathrm{~Hz}$. The EIS data was recorded every 2 hours; $|Z|$ impedance modulus was employed by monitoring corrosion behavior.

The LPR tests were conducted following the recommendations of the ASTM G 59-91 Standard, between -100 and $+100 \mathrm{mV}$ every 8 and 16 hours; in addition polarization curves were done at $60 \mathrm{mV} / \mathrm{min}$ sweep rate.

\section{Results and Discussions}

3.1. Microstructural Characterization. Figure 2(a) shows a $Z$-contrast TEM micrograph of the $\mathrm{Fe}_{40} \mathrm{Al}_{60}$ intermetallic processed by mechanical alloying. In this micrograph, intermetallic particles with size range of 100 and $200 \mathrm{~nm}$ can be observed. Figure 2(b) shows a high-resolution TEM image of individual intermetallic particle with an interplanar spacing of $2.06 \AA$, consistent with the (110) planes of a BCC structure. Figure 3 shows the EDS pattern of the particles before the corrosion tests illustrating the presence of $\mathrm{Fe}$ and $\mathrm{Al}$, as well as small amounts of oxygen. $\mathrm{Cu}$ element in the EDS spectrogram belongs to the grid material. These results confirm the presence of the phase of interest for their corrosion evaluation.

3.2. Electrochemical Tests. Figure 4(a) shows the impedance modulus $|Z|$ for 48 -hour monitoring of the $\mathrm{Fe}_{40} \mathrm{Al}_{60}$ intermetallic corrosion performance in a solution with $\mathrm{pH}=3$ at room temperature. These results show a rather irregular behavior with values oscillating between 2120 and $1600 \Omega$. $\mathrm{cm}^{2}$. However, the LPR tests (Figure 4(b)) show the start values of $R_{p}=2 \mathrm{k} \Omega \cdot \mathrm{cm}^{2}$ which decrease steadily during the elapsed time of the test. After 18 hours of LPR test the $R_{p}$ values reach a stable behavior with fluctuating values around $9000 \Omega \cdot \mathrm{cm}^{2}$ toward the end of the test. The previously behavior can be explained based on the relationships between the solution resistance $\left(R_{s}\right)$, polarization resistance
$\left(R_{p}\right)$, and the impedance modulus $|Z|$ as described by the following:

$$
\begin{gathered}
R_{s}=\lim _{f \rightarrow \infty}|Z|, \\
R_{s}+R_{p}=\lim _{f \rightarrow 0}|Z| .
\end{gathered}
$$

Both equations show the $R_{s}$ and $R_{p}$ dependence of $|Z|$ when $f \rightarrow \infty$ and $f \rightarrow 0$, respectively, where $f$ is the alternating current (AC) frequency. These relationships clearly explain the experimental results. In the present case the $R_{p}$ values tend to decrease and the $R_{s}$ would have a major influence on the $\mathrm{Fe}_{40} \mathrm{Al}_{60}|Z|$ values due to the constant variation in the resistivity of the solution, as showed in Figure 4(a). The electrochemical explanation to this behavior is that aluminum oxidation reaction ((3), anodic reaction) transfers $\mathrm{Al}^{+++}$ions into the test solution by a diffusion mechanism, continuously modifying their ionic conductivity properties:

$$
\mathrm{Al} \longrightarrow \mathrm{Al}^{+++}+3^{\mathrm{e}-}
$$

It has been previously reported that the ionic species diffusion into the corrosion solution occurs in a chemical equilibrium regime that depends on the corrosion solution thermal energy [15]. Figure 4(e) shows EIS Nyquist representation of the $\mathrm{Fe}_{40} \mathrm{Al}_{60}$ corrosion behavior at room temperature and $70^{\circ} \mathrm{C}$, respectively. The corrosion mechanisms presented at both temperatures were principally controlled by diffusion mass transport in the intermetallic surface particle. As mentioned the intermetallic corrosion particles were controlled by diffusion mechanisms. This is clearly evidenced by tendency of the Nyquist curves to form a straight line approximately $45^{\circ}$ with respect the $Z^{\prime}$ axis. This mechanism was presented during the 48 -hour testing at both temperatures.

Figure 4(f) shows the $\mathrm{Fe}_{40} \mathrm{Al}_{60}$ polarization curves in test solution with $\mathrm{pH} 3$ at room temperature, $70^{\circ} \mathrm{C}$, and at low potential scanning ranges. The $\mathrm{Fe}_{40} \mathrm{Al}_{60}$ corrosion potentials $\left(E_{\text {corr }}\right)$ were extracted from these curves being $-180 \mathrm{mV}_{\mathrm{SCE}}\left(61 \mathrm{mV}_{\mathrm{SHE}}\right)$ and $-261 \mathrm{mV}_{\mathrm{SCE}}\left(-20 \mathrm{mV}_{\mathrm{SHE}}\right)$, respectively. Both correspond to $\mathrm{Al} E_{\text {corr }}$ in the intermetallic particles, because $\mathrm{Al}$ is more active and prone to corrosion than Fe. This was confirmed by the EDS results obtained after the electrochemical tests (Figure 7). Transferring the $\mathrm{Al} E_{\text {corr }}$ values to their corresponding Pourbaix diagrams [16] at $\mathrm{pH} 3$, a continuous process without any passive behavior was observed. Solutions with $\mathrm{pH} \leq 3$ induced water dissociation with the consequent evolution of hydrogen dissolved as trivalent ionic aluminum $\left(\mathrm{Al}^{+++}\right)$. Under certain special conditions not well established yet, the dissolution also occurs with the formation of $\left(\mathrm{Al}^{+}\right)$monovalent ions [16].

In addition, tests at $70^{\circ} \mathrm{C}$ indicate $|Z|$ values that decrease significantly in comparison of the tests performed at room temperature. In these tests the maximum and minimum $|Z|$ values observed were $900 \Omega \cdot \mathrm{cm}^{2}$ and $300 \Omega \cdot \mathrm{cm}^{2}$ (Figure 4(c)). The same behavior was noted for the $R_{p}$, where the maximum and minimum values were 


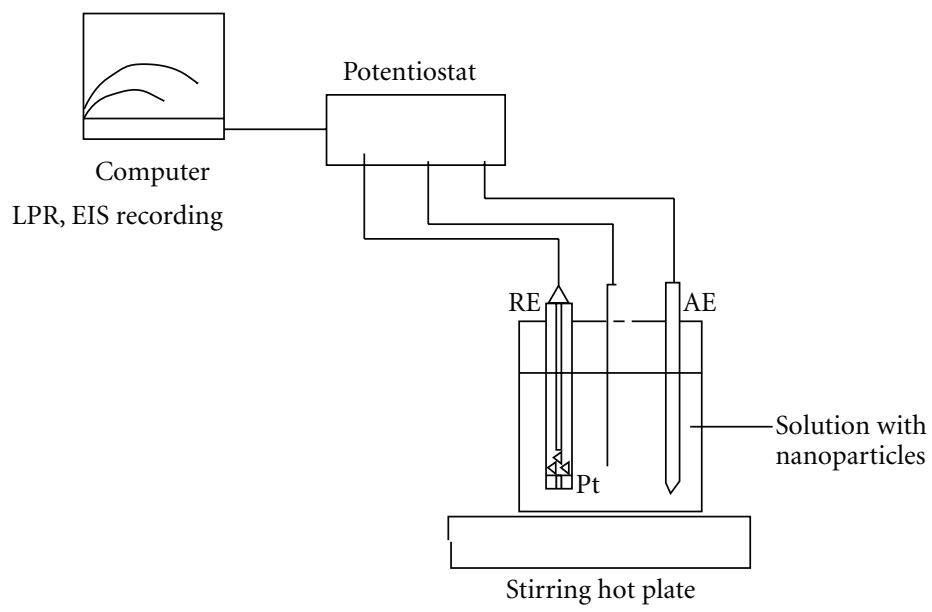

FIGURE 1: Electrochemical cell schematic representation used for the EIS and LPR electrochemical tests.

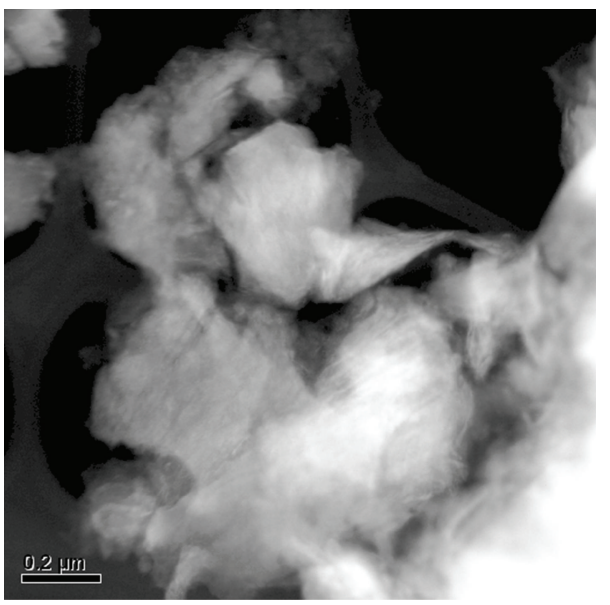

(a)

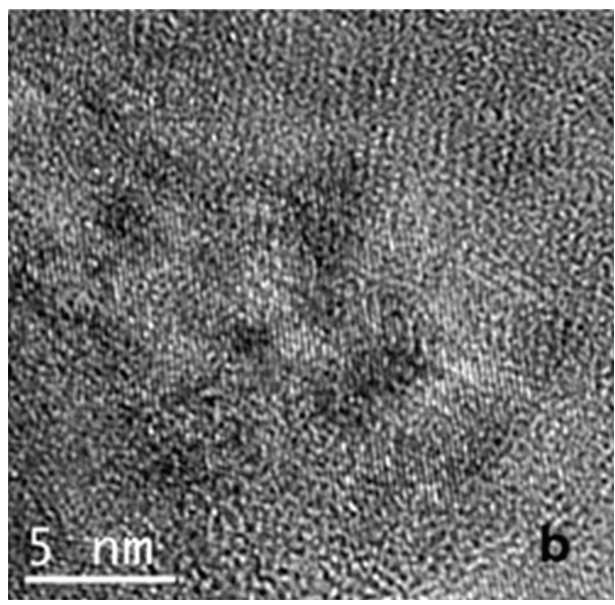

(b)

FIGURE 2: $\mathrm{Fe}_{40} \mathrm{Al}_{60}$ nanoparticle TEM micrographs before the corrosion electrochemical tests, (a) $Z$ contrast and (b) high-resolution microscopy.

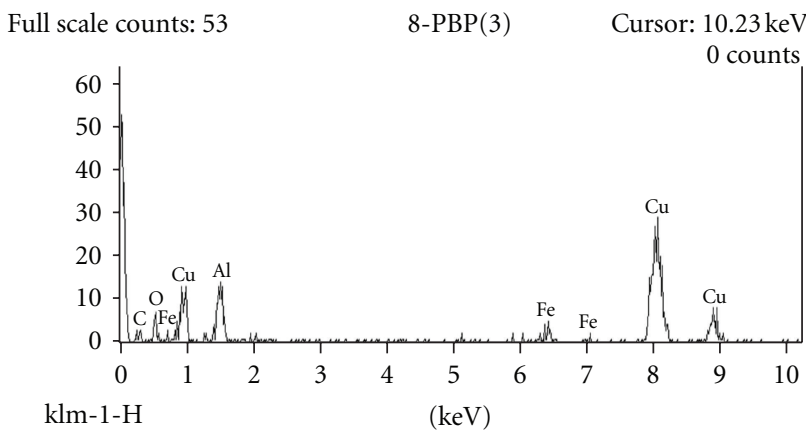

Figure 3: TEM EDS (energy dispersive spectrum) pattern of $\mathrm{Fe}_{40} \mathrm{Al}_{60}$ particles before corrosion electrochemical tests.

$3500 \Omega \cdot \mathrm{cm}^{2}$ and $800 \Omega \cdot \mathrm{cm}^{2}$, as shown in Figure $4(\mathrm{~d})$. From $R_{p}$ values and the Stern Geary equation, the corrosion current density $\left(i_{\text {corr }}\right)$ data was estimated. We observed an increase in the $\left(i_{\text {corr }}\right)$ values during the first 18 hours of test from 0.0014 to $0.0027 \mathrm{~A} / \mathrm{cm}^{2}$. Near the end of the test the $i_{\text {corr }}$ values were stabilized around $\approx 0.0028 \mathrm{~A} / \mathrm{cm}^{2}$. The stabilization of the $i_{\text {corr }}$ maybe indicates that the corrosion diffusion mechanism has been diminished in the interface particles solution. This can be attributed to the monovalent reaction previously mentioned.

One of the principal factors that participate in the evolution of this reaction is the ionic exchange at chemical equilibrium in the metal-solution interface:

$$
\mathrm{Al} \longrightarrow \mathrm{Al}^{+}+\mathrm{e}^{-}
$$

Evidence of this mechanism at $70^{\circ} \mathrm{C}$ can be seen from the Nyquist plot in Figure 4(e). This corroborates the previous results by comparison with the FeAl Nyquist plot at room temperature. The room temperature $|Z|$ limit at low frequencies is greater than $70^{\circ} \mathrm{C}$. This may be due to the increase in temperature originating a catalytic effect on the 
corroding system increasing the corrosion rate. These results were corroborated by the polarization curves obtained at room temperature and $70^{\circ} \mathrm{C}$ (Figure $4(\mathrm{f})$ ). As the $R_{p}$ and $|Z|$ decrease at $70^{\circ} \mathrm{C}$, the $E_{\text {corr }}$ was more negative indicating more susceptibility for corrosion at this temperature than at room temperature. Moreover, the $i_{\text {corr }}$ and $|Z|$ tend to stabilize after 24-hour testing at $\approx 0.027 \mathrm{~A} / \mathrm{cm}^{2}$ and 300 to $400 \Omega \cdot \mathrm{cm}^{2}$, respectively, which eventually occur through the mechanism proposed in (4).

It was observed in EIS tests with $\mathrm{pH} 7$ during the first 24 hours that the $|Z|$ values range from 1023 to $1880 \Omega \cdot \mathrm{cm}^{2}$ for room temperature and 2200 to $11000 \Omega \cdot \mathrm{cm}^{2}$ for $70^{\circ} \mathrm{C}$ (Figures 5(a) and 5(c)). After this period of time and toward the end of the test, there is a $|Z|$ values tendency to increase steadily from 1092 to $1430 \Omega \cdot \mathrm{cm}^{2}$ (room temperature) and from 2200 to $9000 \Omega \cdot \mathrm{cm}^{2}\left(70^{\circ} \mathrm{C}\right)$. At this stage, the corrosion mechanism is controlled by a diffusion process as evidenced by their corresponding Nyquist plots on Figure 5(e).

The $E_{\text {corr }}=-108 \mathrm{mV}_{\mathrm{SCE}}\left(133 \mathrm{mV}_{\mathrm{SHE}}\right)$ obtained at room temperature and estimation from the polarization curves are showed in Figure 5(f). Introducing this value in their Pourbaix diagram with a $\mathrm{pH} 7$ for pure water, can be observed that it is forms a layer known as bayerite.

$\mathrm{Al}_{2} \mathrm{O}_{3} \cdot 3 \mathrm{H}_{2} \mathrm{O}$. After corrosion test, evidence for the formation of bayerite phase on the surface of $\mathrm{Fe}_{40} \mathrm{Al}_{60}$ particles was previously presented in HRTEM images and from EDS analysis (Figures 2 and 3). However, this layer is not protective or contributes to decreasing the corrosion rate at the particle surfaces due to its high solubility in pure water.

Furthermore, the bayerite dissolution could reduce the $\mathrm{pH}$ solution [16]. This fact was confirmed by the results of $\mathrm{pH}$ measurements obtained directly from the test solution at $70^{\circ} \mathrm{C}$, as shown in Figure 5(c). After $48 \mathrm{hrs}$ of testing, the $\mathrm{pH}$-solution measurement decreased from 7 to 6.68 . This indicates the presence of bayerite at surface particles even at this temperature. Thus, the randomness in the $|Z|$ values at early stages of the corrosion test would depend on the variation in $R_{p}$ values originated by the formation and dissolution of this oxide nonprotective layer.

Subsequently, the impedance modulus values for both temperatures tend to increase constantly until the end of the tests corrosion. Thus, (3) as the test results of LPR (Figures 5(b) and 5(d)) indicates that this behavior in the impedance modulus is a function of the $R_{p}$ which steadily increases, and consequently the $i_{\text {corr }}$ decreases. These results could indicate the transformation of the bayerite to the formation of a film of $\mathrm{Al}(\mathrm{OH})_{3}$ on the surface particles. This takes place when $\mathrm{Al}$ reacts with the hydroxyl $\mathrm{OH}^{-}$ ions formed for the potential levels $\left(E_{\text {corr }}\right)$ obtained in both temperature conditions, according to their potential-pH equilibrium water diagram. Such formations of aluminum oxide are known as aging [16] and are a function of exposure corrosion time and $\mathrm{pH}$.

Eventually, the $\mathrm{OH}^{-}$formation increases with the increment in temperature, which induces the $\mathrm{pH}$ increment to 9.7. The $\mathrm{pH}$ was measured directly from the corrosion test solution after 5 -day testing (Figure $5(\mathrm{~d})$ ). In this way, the increment of $\mathrm{OH}^{-}$ions activates the $\mathrm{Al}(\mathrm{OH})_{3}$ formation on the surface particles increasing $R_{p}$ values. It is not clear if the film has passive properties at the particle surfaces, but the results indicate that at least reduce their corrosion rates considerably at both temperatures, showing $i_{\text {corr }}$ values of 0.0016 (room temperature) and $0.0006 \mathrm{~A} / \mathrm{cm}^{2}\left(70^{\circ} \mathrm{C}\right)$.

For a $\mathrm{pH} 11$ the scenario was quite different. Figure 6(a) shows the Nyquist plots obtained at room temperature and $70^{\circ} \mathrm{C}$. The Nyquist plots show a partial semicircle that does not reach the limit at low frequencies. This behavior is characteristic when the relationship resistance-capacitance (RC) became large. The mechanism associated with control of this corrosion performance is mainly by charge transfer and can occur in passive metals or in metal which forms a porous surface conductive film with high capacitance [13]. This could indicate that $\mathrm{Fe}_{40} \mathrm{Al}_{60}$ particles form at their surface a $\mathrm{Al}(\mathrm{OH})_{3}$ layer due to $\mathrm{Al}$ that tends to form under alkaline solutions this type of unstable precipitate [16]. This was confirmed by the TEM images shown in Figure 6(b), in which two different phases were presented. In these TEM images, the more intensive zones indicate a phase with more atomic weight (metallic phase); meanwhile the zones with minor contrast show the corrosion products generated. Figure 6(c) is a high-resolution TEM image of the isolated corroded phase. The interatomic distances from the image indicate a value $2.55 \AA$ which corresponds to the plane (104) of this hydrated phase. A postcorrosion EDS analysis showed in Figure 7 revealed that the regions of lower intensity correspond to the minor contrast zones illustrated in Figure 6(c), which reveals $\mathrm{O}$ and $\mathrm{Al}$ in a high percentage. This indicates corrosion products at the particle surfaces, formed after the corrosion electrochemical tests.

For 48 hours of corrosion test performed at room temperature, the impedance modulus (Figure 8(a)) presents random values with oscillating resistance between 1300 and $2300 \Omega \cdot \mathrm{cm}^{2}$. However, their corresponding $R_{p}$ values (Figure 8(b)) have a tendency to increase from 3500 to $8500 \Omega \cdot \mathrm{cm}^{2}$. This means that due to charge transfer of the formed corrosion layer, the variation of conductivity in $R_{s}$ was the determining factor of $|Z|$ data behavior according to the relationship showed by (3).

After the solution was treated for 24 hours at $70^{\circ} \mathrm{C}$, the $|Z|$ values show a tendency to increase gradually (Figure $8(\mathrm{c})$ ). As previously mentioned, this is related to the catalytic effect of the temperature. In this case, there is accelerating and homogenizing of the electronic exchange between charges produced during the transfer in the metalsolution interface. As consequence of this an increase of the corrosion rates of the particles was obtained. This was confirmed by analyzing the $R_{p}$ data, which are decreasing in their maximum $R_{p}$ values $\left(\sim 6000 \Omega \cdot \mathrm{cm}^{2}\right)$ at $70^{\circ} \mathrm{C}$ (Figure $8(\mathrm{~d})$ ) in comparison to the $R_{p}$ values exhibit at room temperature, as well as, the decrement in the $Z^{\prime}$ and $Z^{\prime \prime}$ values in Nyquist plot, as shown in Figure 6(a).

Finally, the $\mathrm{Fe}_{40} \mathrm{Al}_{60}$ polarization curves for the $\mathrm{pH} 11$ solution at room temperature and $70^{\circ} \mathrm{C}$ are observed in Figure $8(\mathrm{e})$. The $E_{\text {corr }}$ values were -40 and $48 \mathrm{mV}_{\mathrm{SCE}}$ at both temperature conditions. These values were higher than those obtained at the $\mathrm{pH} 3$ and $\mathrm{pH} 7$ solutions. This means large times required to reach equilibrium between cathodic and anodic reactions. Accordingly, this might influence the large 


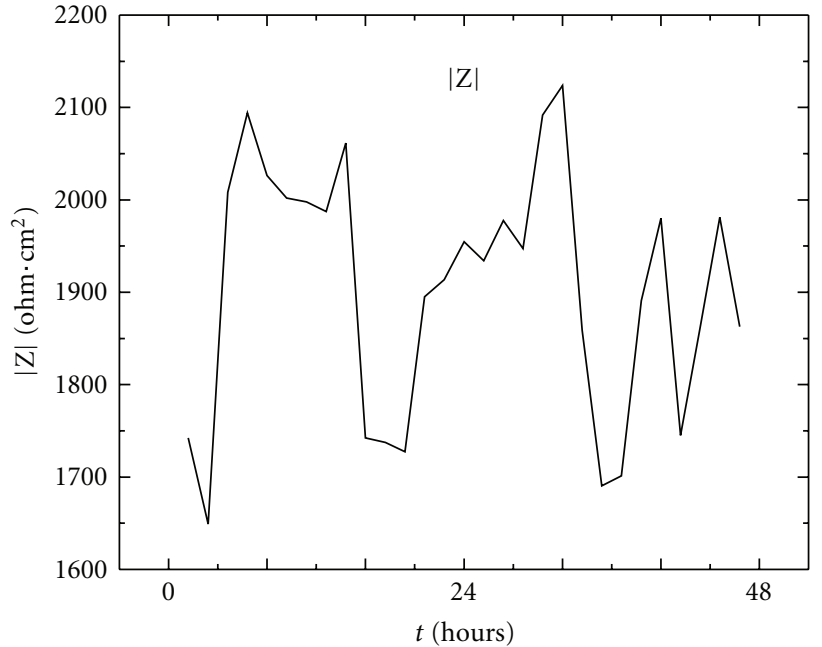

(a)

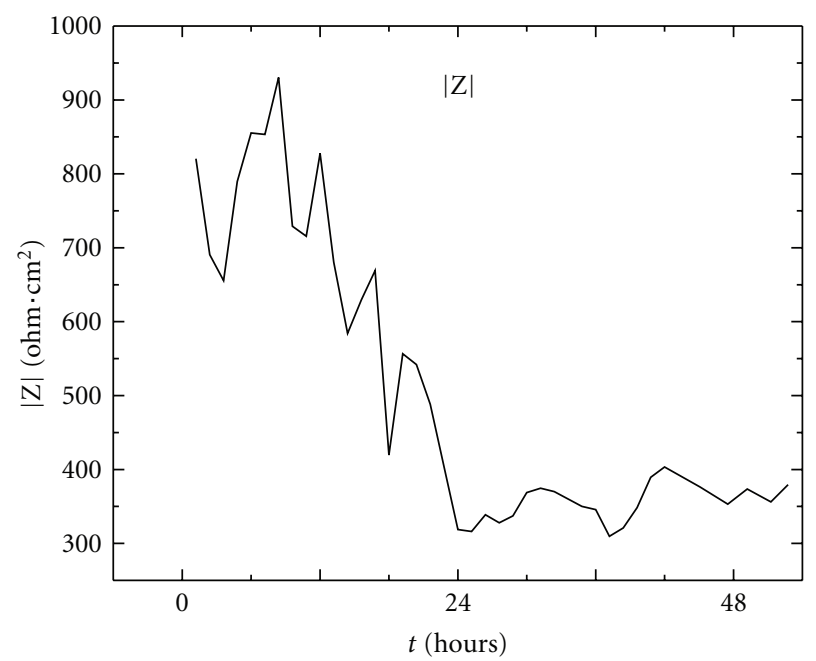

(c)

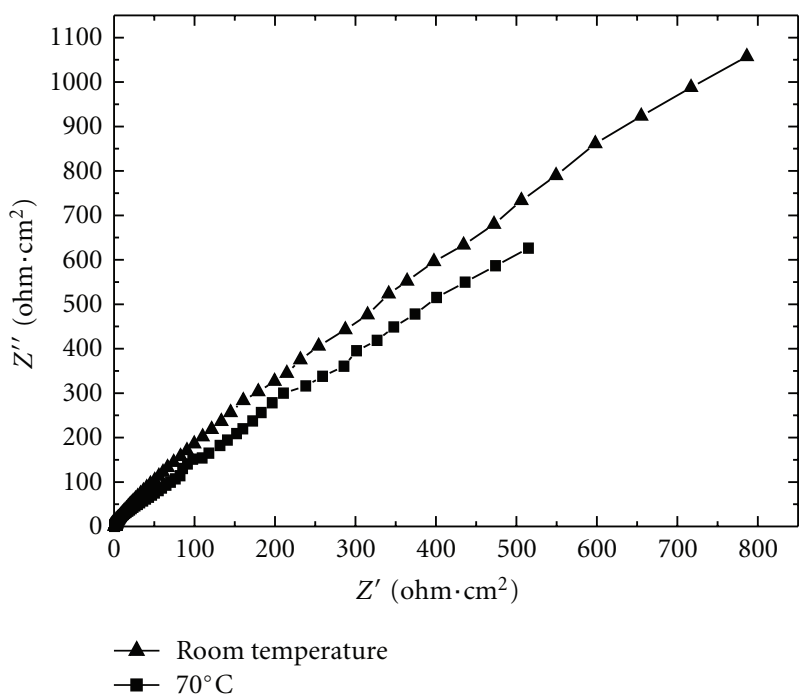

(e)

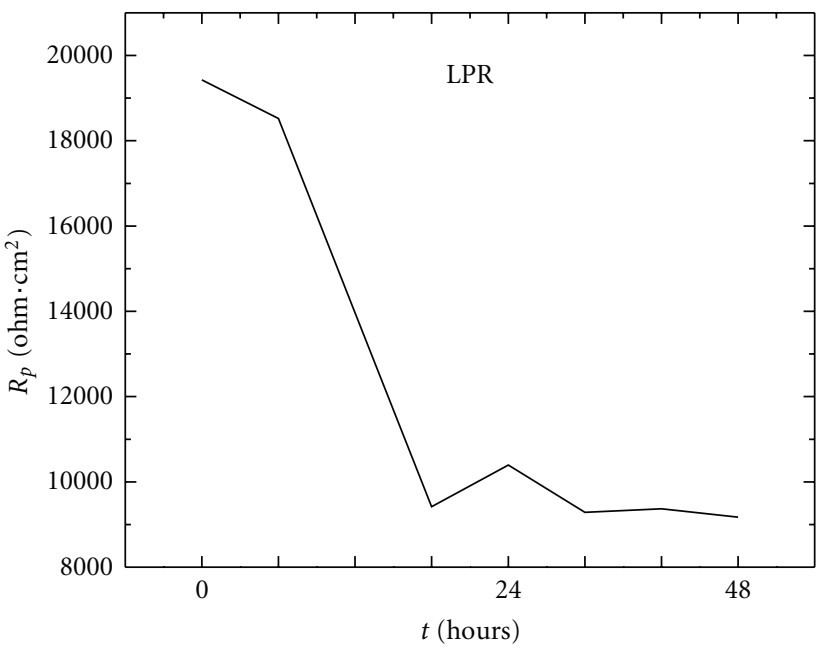

(b)

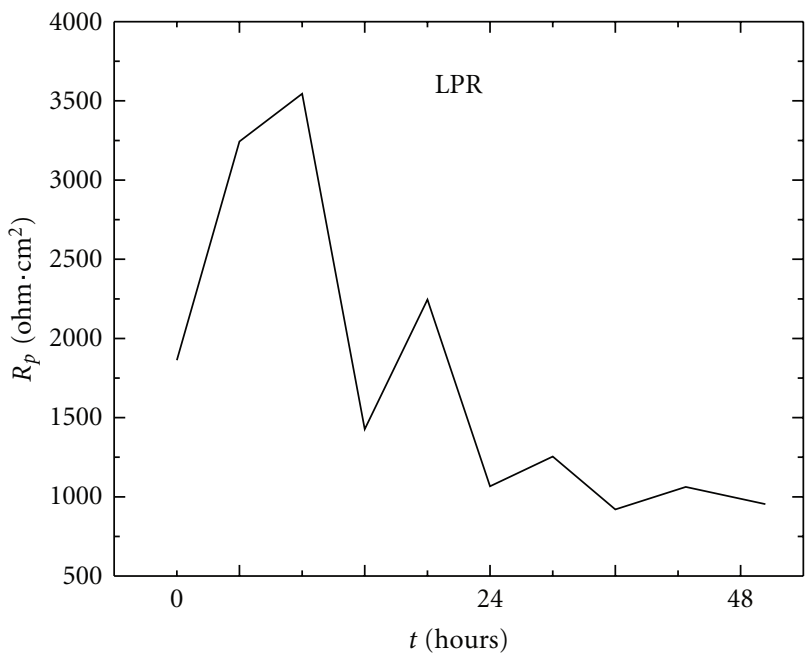

(d)

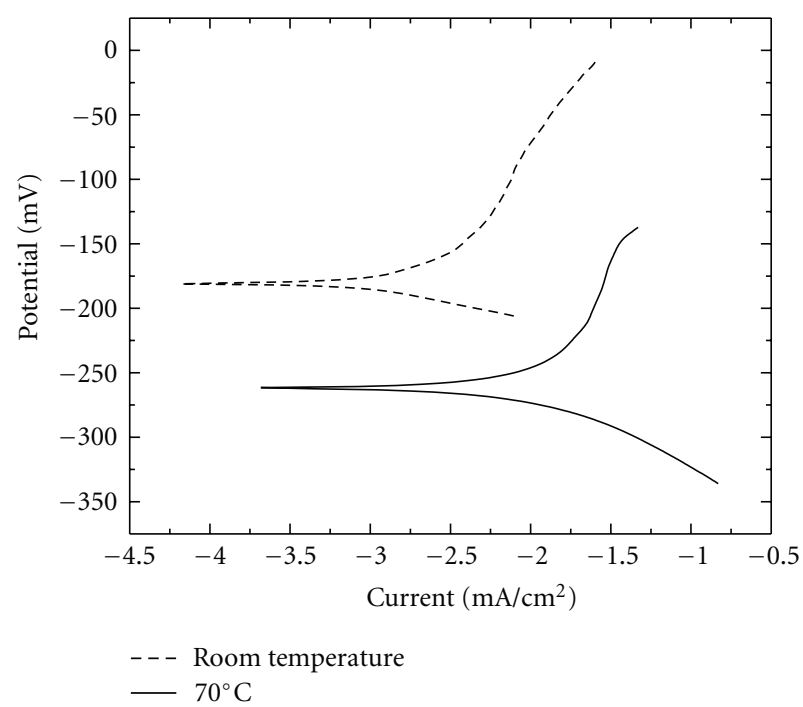

(f)

Figure 4: Electrochemical tests plots in the $\mathrm{pH} 3$ solution, (a) $|Z|$ at room temperature for 48 hours, (b) $R_{p}$ at room temperature for 48 hours, (c) $|Z|$ at $70^{\circ} \mathrm{C}$ for 48 hours, (d) $R_{p}$ at $70^{\circ} \mathrm{C}$ for 48 hours, (e) EIS Nyquist plot at room temperature and $70^{\circ} \mathrm{C}$, and (f) polarization curves at room temperature and $70^{\circ} \mathrm{C}$. 


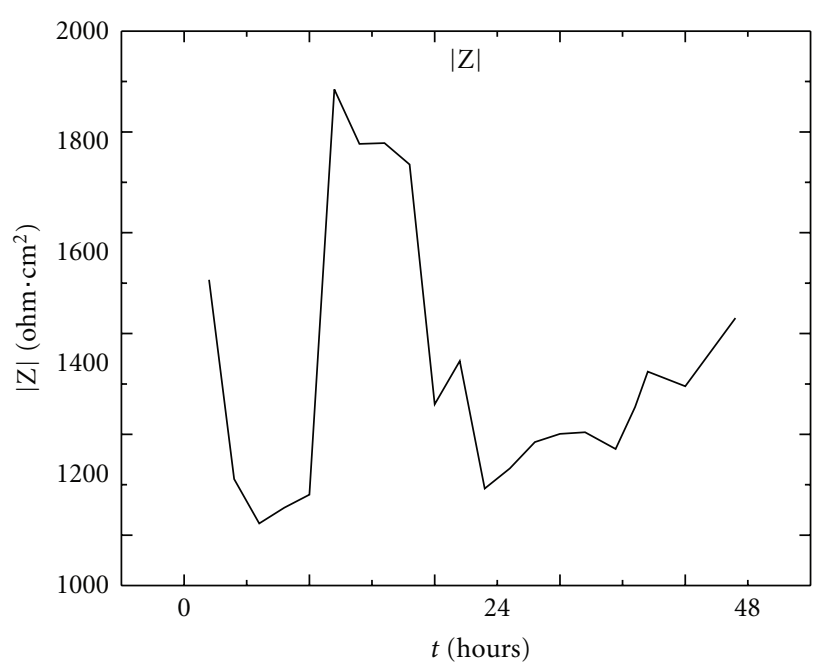

(a)

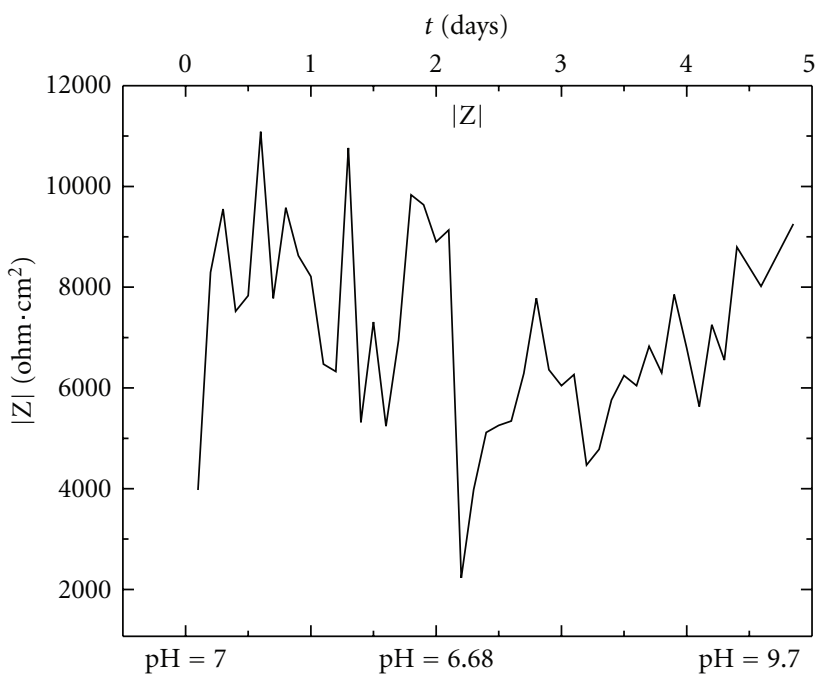

(c)

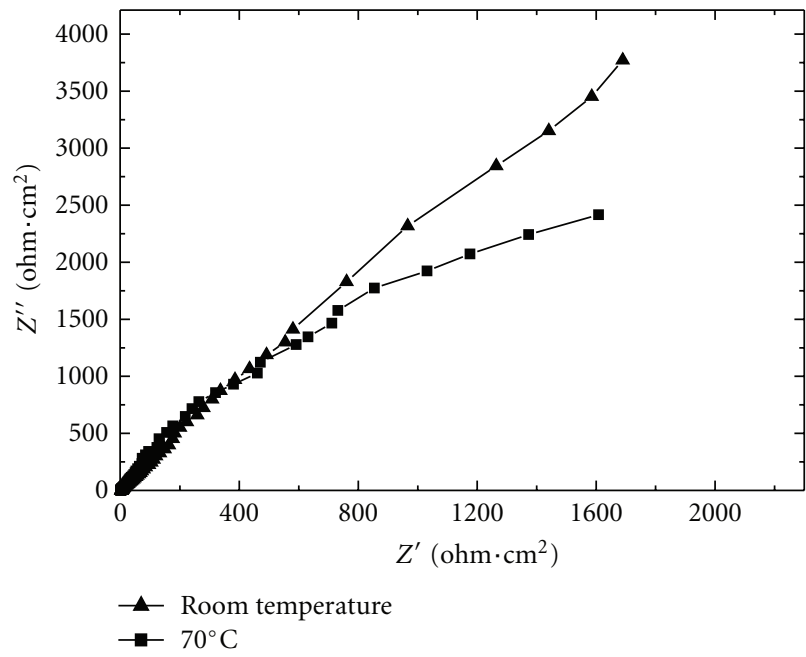

(e)

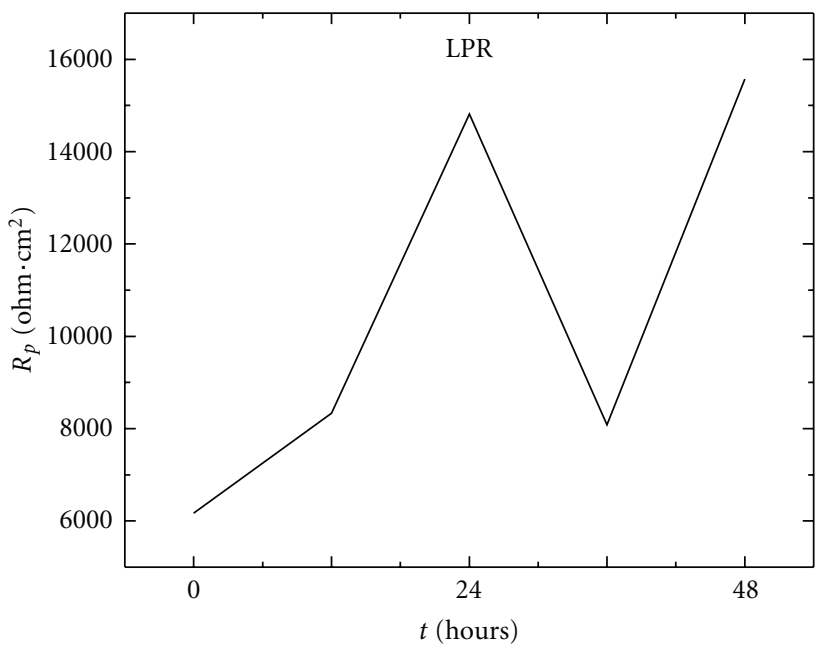

(b)

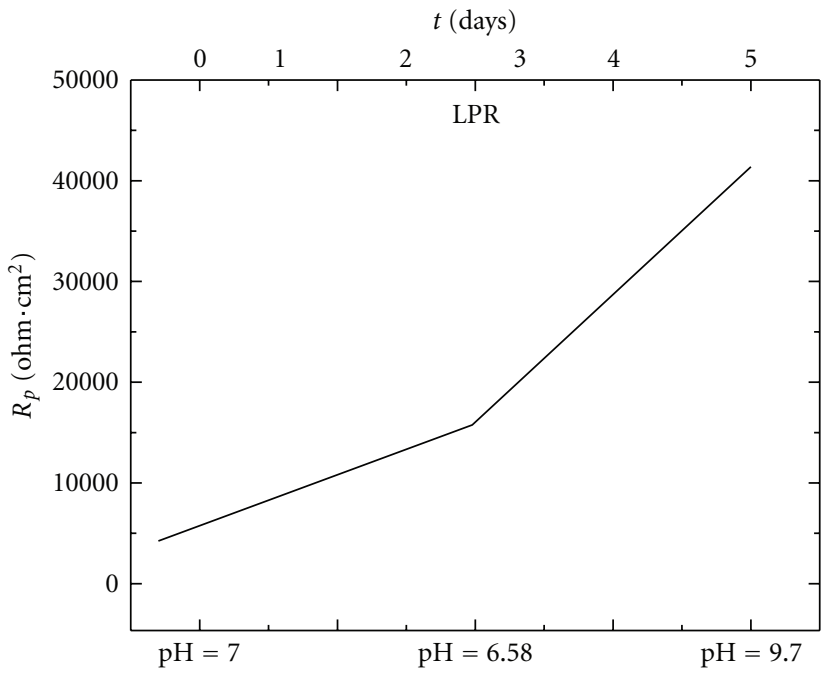

(d)

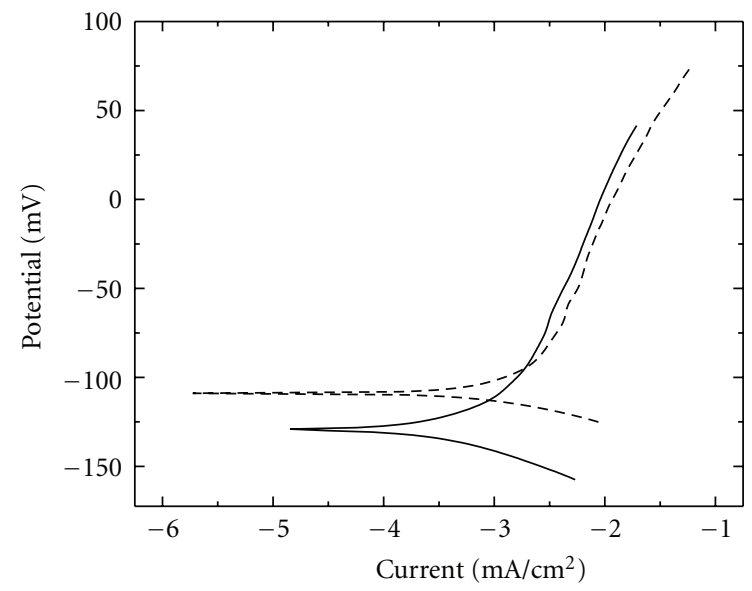

- - - Room temperature

$-70^{\circ} \mathrm{C}$

(f)

Figure 5: Electrochemical tests plots in the $\mathrm{pH} 7$ solution, (a) $|Z|$ at room temperature for 48 hours, (b) $R_{p}$ at room temperature for 48 hours, (c) $|Z|$ at $70^{\circ} \mathrm{C}$ for 5 days, (d) $R_{p}$ at $70^{\circ} \mathrm{C}$ for 48 hours, (e) EIS Nyquist plot at room temperature and $70^{\circ} \mathrm{C}$, and (f) polarization curves at room temperature and $70^{\circ} \mathrm{C}$. 


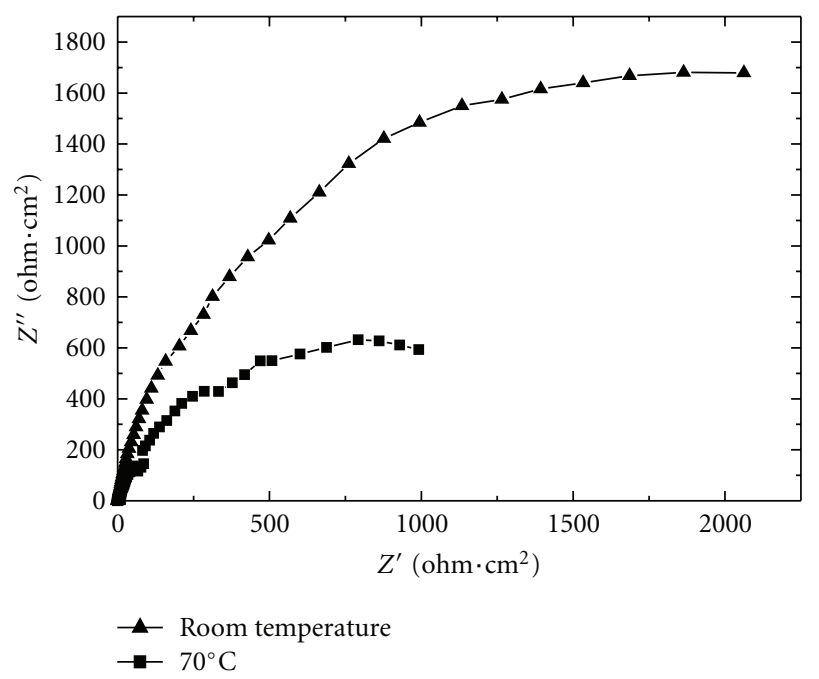

(a)

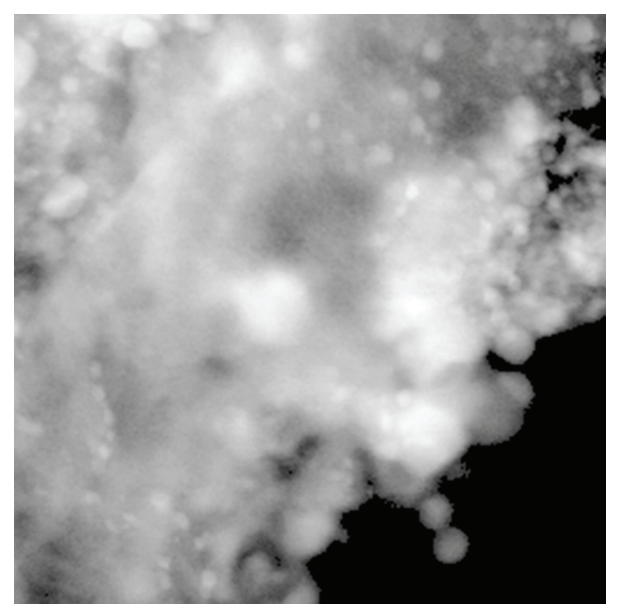

(b)

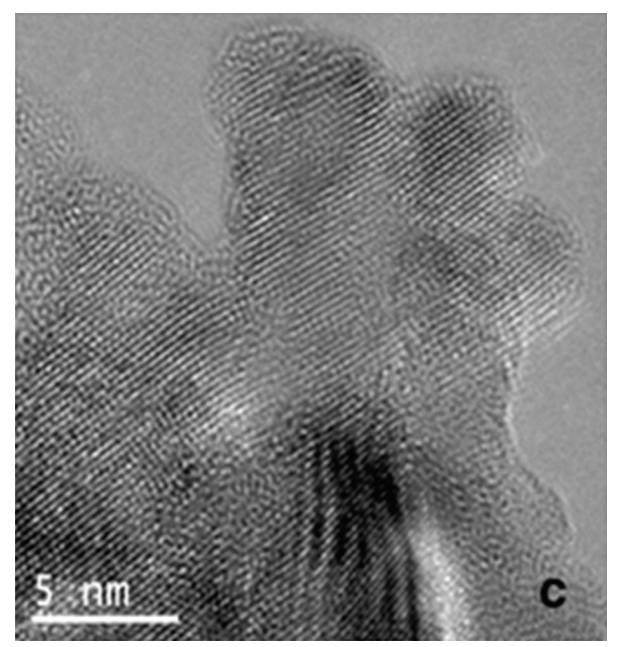

(c)

FIgURE 6: (a) EIS Nyquist plots in pH 11 solution at room temperature and $70^{\circ} \mathrm{C}$, (b) FeAl particle TEM micrograph obtained by $Z$ contrast after corrosion tests, and (c) FeAl TEM high-resolution image after corrosion tests.

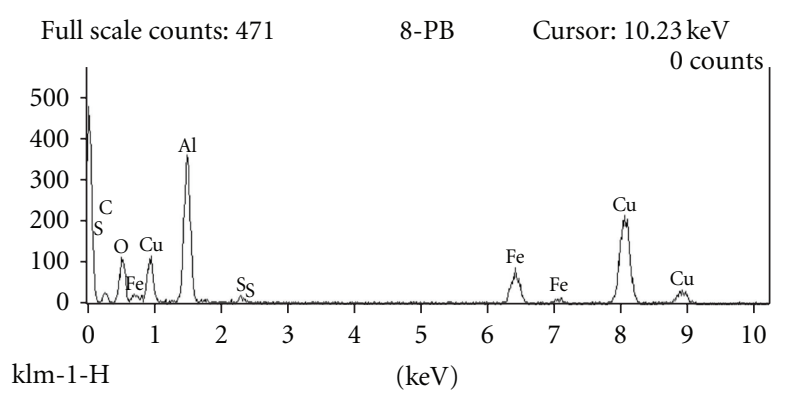

FIGURE 7: TEM EDS (energy dispersive spectrum) pattern of FeAl particles after corrosion electrochemical tests.

values obtained from the $I_{\text {corr }}$, reaching maximum values of $0.006 \mathrm{~mA} / \mathrm{cm}^{2}$.

\section{Summary}

The corrosion behavior of the $\mathrm{Fe}_{40} \mathrm{Al}_{60}$ nanostructured intermetallic particles was strongly affected by the temperature and different types of oxides formed at the particles surfaces. The oxide type formed can vary according to its solution solubility that depends on whether the solutions were acid/basic of pure water. In any case, the particles corrosion does not show localized corrosion, a passive behavior, or pitting, presenting principally uniform corrosion along the particles surfaces areas.

The corrosion potentials obtained from $\mathrm{Fe}_{40} \mathrm{Al}_{60}$ nanostructured do not correspond to any bulk pure $\mathrm{Al}$ or Al-alloys mostly reported at $-1700 \mathrm{mV}_{\text {SCE }}$. This suggests that the $\mathrm{Fe}_{40} \mathrm{Al}_{60}$ nanoparticles are responsible for their new corrosion potentials values reported in this work. This may be due to a high number of superficial atoms developed by the nanostructures formed by mechanical alloying, compared with conventional macro-Al-alloys. The nanocrystals increase the time required to reach electrochemical equilibrium between anodic and cathodic partial reactions, leading to more positive corrosion potentials values. However, further corrosion studies with different size of $\mathrm{Fe}_{40} \mathrm{Al}_{60}$ nanoparticles will be carried out to corroborate these results.

\section{Conclusions}

(1) The possibility of the $\mathrm{Fe}_{40} \mathrm{Al}_{60}$ nanoparticles corrosion monitoring in suspension was demonstrated by conventional bulk electrochemical techniques and setups such as those employed by EIS, LPR, and electrochemical polarization techniques, for long periods of time.

(2) The nanoparticle corrosion behavior depends on testing temperature, time, and their corrosion products formation principally in the form of aluminum oxides. The oxide solubility in the different testing solutions proves to be also an important factor to determine their corrosion behavior. 


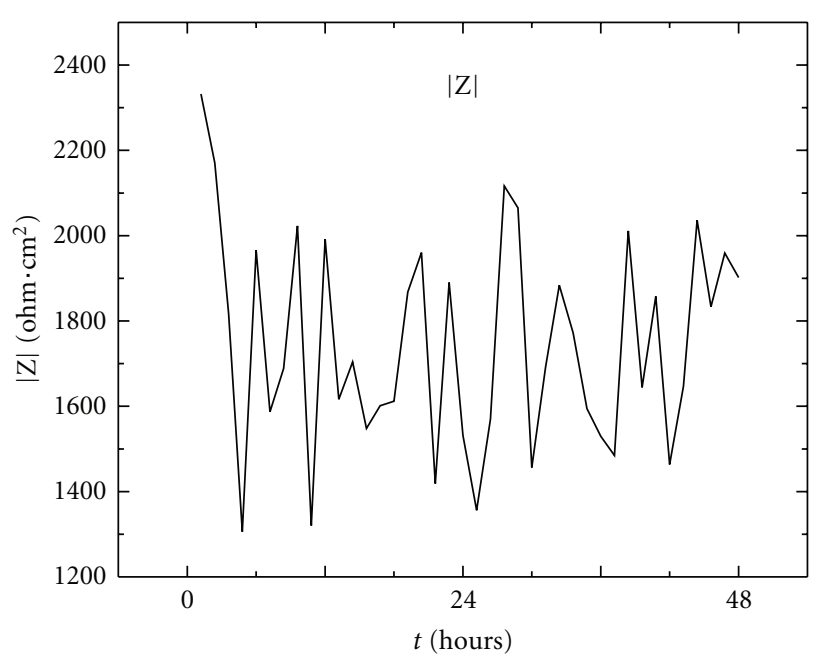

(a)

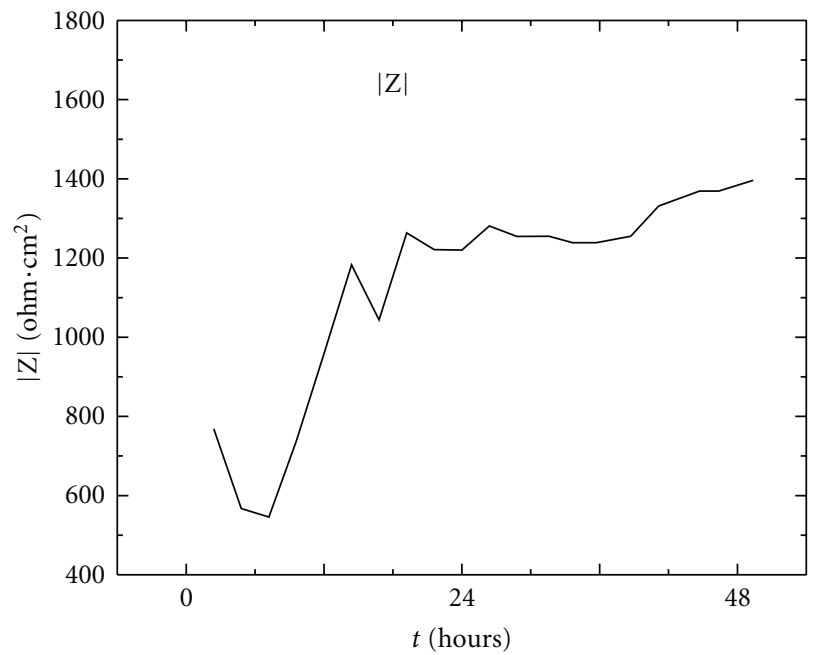

(c)

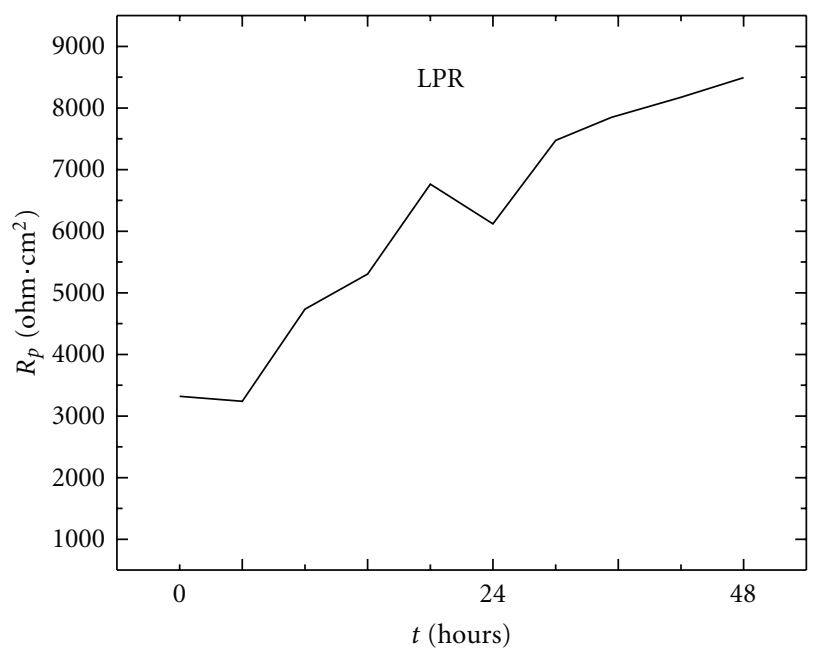

(b)

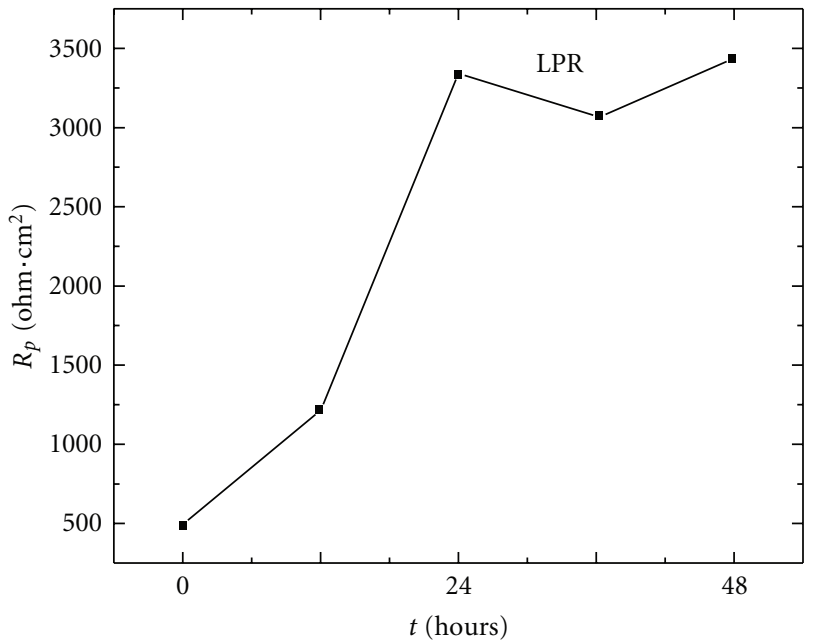

(d)

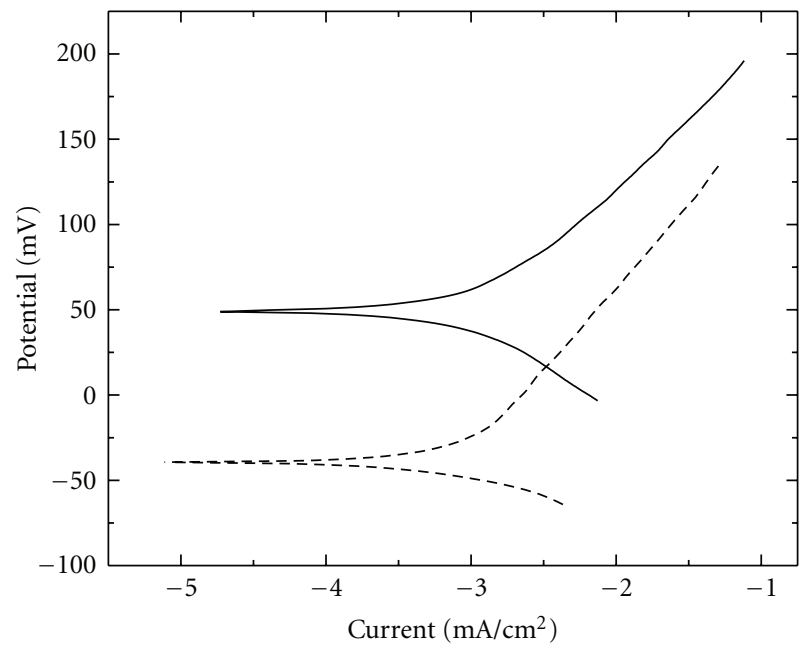

--- Room temperature

$-70^{\circ} \mathrm{C}$

(e)

Figure 8: Electrochemical tests plots in the $\mathrm{pH} 11$ solution, (a) $|Z|$ at room temperature for 48 hours, (b) $R_{p}$ at room temperature for 48 hours, (c) $|Z|$ at $70^{\circ} \mathrm{C}$ for 48 hours, (d) $R_{p}$ at $70^{\circ} \mathrm{C}$ for 48 hours, and (e) polarization curves at room temperature and $70^{\circ} \mathrm{C}$. 
(3) The results show that the nanoparticles corrosion mechanisms depend on the $\mathrm{pH}$ of the solution, showing diffusion mechanisms at $\mathrm{pH}$ values of 3 and 7 and charge transfer mechanism at a $\mathrm{pH}$ value of 11 .

(4) Under all environment conditions (temperature, $\mathrm{pH}$ ) the nanoparticles do not present any localized corrosion type; instead it always shows uniform corrosion along the particles surfaces areas.

(5) The $\mathrm{Fe}_{40} \mathrm{Al}_{60}$ nanostructured intermetallic superficial atom density changes its corrosion properties as compared with bulk pure $\mathrm{Al}$ and $\mathrm{Al}$-alloys.

\section{Acknowledgments}

The authors acknowledge Conacyt support through their Convocatoria 2009 de Estancias posdoctorales y sabaticas vinculadas al fortalecimiento de la calidad del posgrado nacional modalidad A, "Convocatoria de Investigación Básica 2005,” Project no. 48716-25535. The authors would like to thank I. Puente, Faculty of Chemistry, UNAM, for SEM and TEM microscopy assistance.

\section{References}

[1] G. McKamey, "Iron aluminides," in Physical Metallurgy and Processing of Intermetallic Compounds, N. S. Stoloff and V. K. Sikka, Eds., International Thomson Publishing, 1996.

[2] R. W. Cahn, "Historical perspective on the development of aluminides," in Proceedings of the International Symposium on Nickel and Iron Aluminides, American Society for Microbiology, Cincinnati, Ohio, USA, 1996.

[3] C. Testani, A. Di Gianfrancesco, D. Tassa, and D. Pocci, "FeAl intermetallics and applications," in Proceedings of the International Symposium on Nickel and Iron Aluminides, American Society for Microbiology, Cincinnati, Ohio, USA, 1996.

[4] S. C. Deevi and V. K. Sikka, "An overview on properties, processing, and applications I ntermetalllics," in Proceedings of the International Symposium on Nickel and Iron Aluminides, American Society for Microbiology, Cincinnati, Ohio, USA, 1996.

[5] S. Mohan and S. Srivastava, "Surface behaviour of as-Cast AlFe intermetallic composites," Tribology Letters, vol. 22, no. 1, pp. 45-51, 2006.

[6] M. Salazar, R. Perez, and G. Rosas, "The effect of Li, Ce and $\mathrm{Ni}$ additions on the microstructure and the mechanical properties in the AlFe intermetallic system," Materials Science Forum, vol. 426-432, no. 3, pp. 1837-1842, 2003.

[7] V. Castel, J. B. . Youssef, and C. Brosseau, "Broadband ferromagnetic resonance measurements in $\mathrm{Ni} / \mathrm{ZnO}$ and $\mathrm{Ni} \gamma$ $\mathrm{Fe}_{2} \mathrm{O}_{3}$," Journal of Nanomaterials, vol. 2007, Article ID 27437, 16 pages, 2007.

[8] S. Kamrani, R. Riedel, S. M. Seyed Reihani, and H. J. Kleebe, "Effect of reinforcement volume fraction on the mechanical properties of Alg-SiC nanocomposites produced by mechanical alloying and consolidation," Journal of Composite Materials, vol. 44, no. 3, pp. 313-326, 2010.

[9] M. Zakeri and M. R. Rahimpour, "Synthesis of FeAl-TiC nanocomposite powder via mechanical alloying and subsequent annealing," Powder Metallurgy, vol. 54, no. 3, pp. 278$285,2011$.
[10] J. G. Gonzalez-Rodriguez, M. Salazar, Luna-Ramirez, J. Porcayo-Calderon, G. Rosas, and A. MartinezVillfane, "Effect of $\mathrm{Li}, \mathrm{Ce}$ and $\mathrm{Ni}$ on the corrosion resistance of $\mathrm{FeAl}$ in molten $\mathrm{Na}_{2} \mathrm{SO}_{4}$ and $\mathrm{NaVO}_{3}$," High Temperature Materials and Processes, vol. 23, no. 3, p. 177, 2004.

[11] J. G. Gonzalez-Rodriguez, M. Gonzalez-Castaneda, M. Cuellar-Hernandez, G. Dominguez-Patino, and G. Rosas, "Effect of $\mathrm{Ni}$ on the corrosion behavior of FeAl intermetallics in simulated human body fluid," Journal of Solid State Electrochemistry, vol. 12, p. 707, 2007.

[12] R. Esparza, G. Rosas, J. A. Ascencio, and R. Pérez, "Effects of minor element additions to the nanocrystalline FeAl intermetallic alloy obtained by mechanical alloying," Materials and Manufacturing Processes, vol. 20, no. 5, pp. 823-832, 2005.

[13] J. Chen, B. J. Wiley, and Y. Xia, "One-dimensional nanostructures of metals: large-scale synthesis and some potential applications," Langmuir, vol. 23, no. 8, pp. 4120-4129, 2007.

[14] G. Rosas, R. Esparza, H. B. Liu, J. A. Ascencio, and R. Pérez, "Preparation of AlFe nanoparticles by mechanical alloyed technique," Journal of Nanoscience and Nanotechnology, vol. 5, pp. 2133-2137, 2005.

[15] E. Treybal Robert, Mass Transfer Operations, McGraw-Hill, Singapore, 2nd edition, 1985.

[16] M. Pourbaix, Atlas of Electrochemical Equilibrium in Aqueous Solutions, NACE, Houston, Tex, USA, 2nd edition, 1974. 

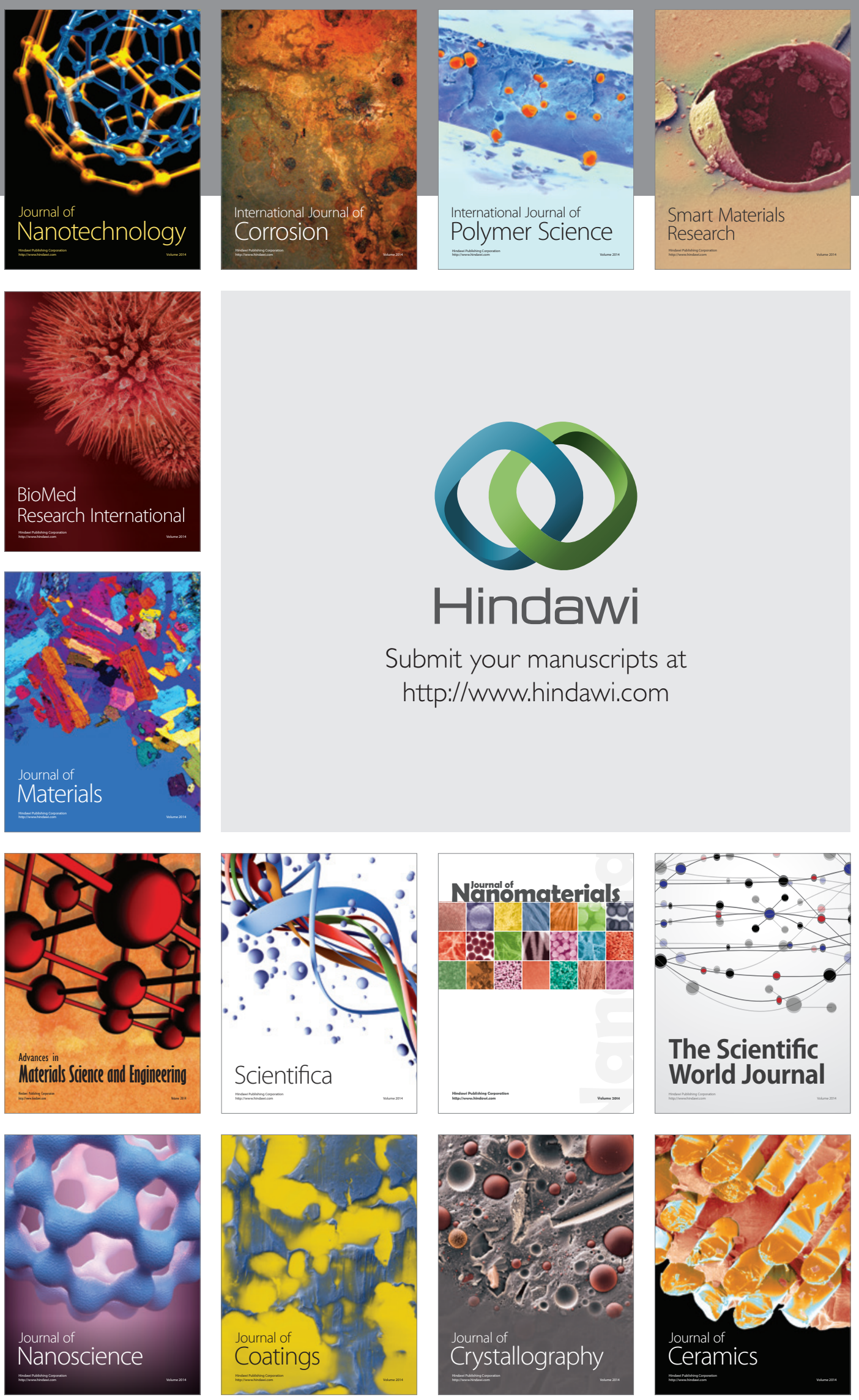

The Scientific World Journal

Submit your manuscripts at

http://www.hindawi.com

\section{World Journal}

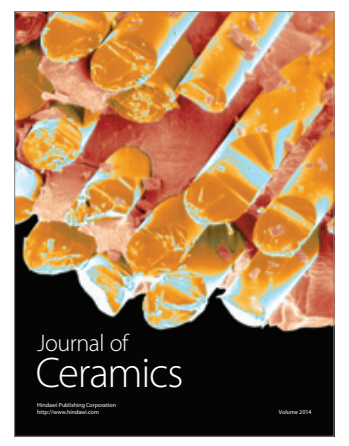

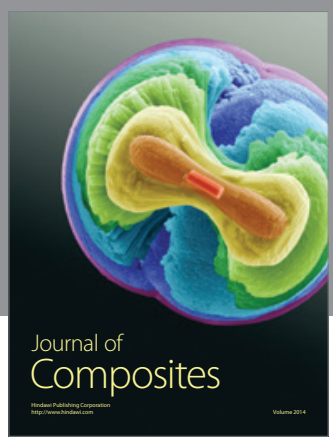
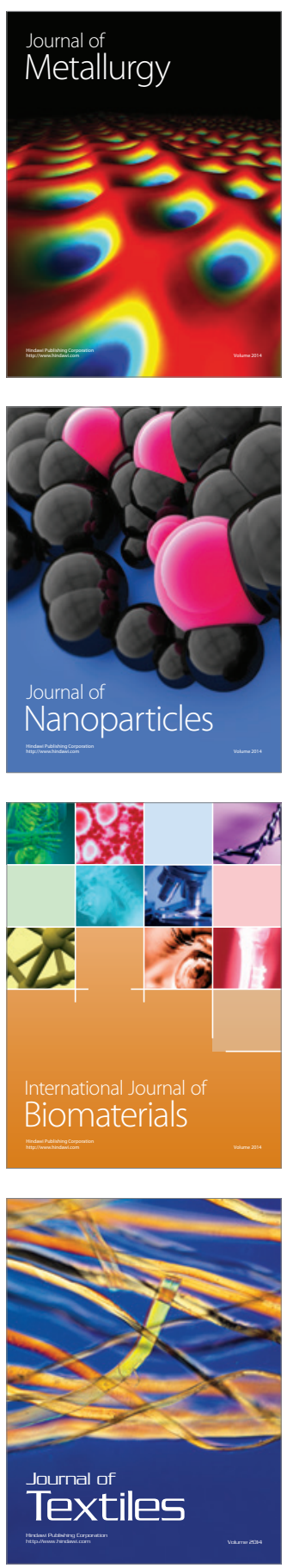